\title{
FOREIGN EXPERIENCE FOR FINANCING SMALL AND MEDIUM BUSINESS
}

\author{
Valentyn Halunko ${ }^{1}$, Vira Halunko², Maryna Savyuk ${ }^{3}$
}

\begin{abstract}
The aim of the article is to study the peculiarities of the financial and credit mechanism of supporting small and medium enterprises in foreign countries with the purpose of identification of key areas for the development of financial and credit support for small and medium enterprises in Ukraine. The subject of the study is the foreign experience of financing small and medium-sized businesses. Methodology. The research is based on a comparison of financial and credit support of small and medium business in Ukraine and in foreign countries. The advantages and disadvantages of different support systems for small and medium-sized enterprises are determined on the basis of an analysis of the specifics of financing small and medium-sized businesses in Germany, the USA, the UK, Italy, Japan, and some other countries. The possibilities and limits of the application of positive foreign experience in this area are determined on the basis of a comparative legal study of certain provisions of Ukrainian legislation. The results of the study showed that the peculiarities of the financial and credit mechanism for supporting small and mediumsized businesses in foreign countries, which were studied, are as follows: the predominance of indirect support methods, provision of state financial help only on a competitive, turnaround, and paid basis; effectively functioning system of state guarantee of loans, which were provided to small businesses by commercial banks (guarantee from 60 to $90 \%$ of the loan); creation of a network of special banks, which serve small businesses at different levels; strong financial stimulation for small businesses in their innovation activity; stimulating taxation system and special depreciation procedure; creation of conditions for equal access for all entrepreneurs to information and consulting services (especially on taxation, lending, and insurance issues). Practical implications. The positive experience of financing small and medium business shows that the foreign practice of functioning of the financial and credit mechanism for supporting small business is not based on the fact that, on preferential terms, small enterprises can receive all the necessary financial and credit resources for their development and support small business at all costs. But this practice is aimed to create a favourable economic and legal climate that allows small businesses not only to survive but also to successfully develop. Correlation/originality. A comparative analysis of small and medium business financing systems is the basis for developing the most promising directions for the development of domestic legislation in this field.
\end{abstract}

Key words: financial and credit mechanism, small and medium business, venture financing, preferential taxation.

JEL Classification: O23, E52, H21

\section{Introduction}

Small and medium-sized businesses traditionally play an important role in the functioning of the economy of any country. Thus, the share of small and medium-sized businesses in developed economies usually exceeds $90 \%$ of the total number of operating companies. Small and medium-sized businesses are the drivers for introducing innovations both in production and in the service sector. Despite the highest technological flexibility, small and medium-sized businesses are more susceptible to market fluctuations and crises, with no stock strength that is typical of most large enterprises.

The SME sector also has an important social function, providing jobs for about $75 \%$ of employees.

Against this background, it can be argued that small and medium-sized enterprises should develop and receive financial support from the state and credit institutions along with large enterprises. Small and medium-sized businesses should not be opposed to large enterprises. But the small and medium-sized

\footnotetext{
Corresponding author:

${ }^{1}$ Research Institute of Public Law, Ukraine.

E-mail: halunko@i.ua

${ }^{2}$ Kherson State University, Ukraine.

E-mail: vera.galunko.00@i.ua

${ }^{3}$ Research Institute of Public Law, Ukraine.

E-mail: savyukmaryna@i.ua
} 
business in difficult times experienced by most large enterprises can be a reliable source of budget revenues and a means of reducing social tension by creating jobs. In developed countries, the share of small and medium-sized enterprises loans in GDP is $13 \%$, while in developing countries only 3\% (Synoverskyi, 2016).

Since Ukraine can be considered a country with a developing economy, it will be appropriate to compare its indicators of lending to the SME sector with indicators of countries close to Ukraine in terms of economic development, such as Bolivia, Paraguay, Uruguay, Peru, Colombia, etc. (COSME).

As stated in the National Program for the Promotion of Small Business Development in Ukraine, the situation with the financing of small business requires the urgent construction of a non-bank financial and credit sector aimed exclusively at small businesses and selfemployment. Consequently, the financial and lending support of small business aimed at should be aimed at:

- formation of a network of regional funds for supporting entrepreneurship and credit and guarantee institutions;

- development and introduction of effective credit and guarantee mechanisms of micro-crediting of small business entities;

- creation and support of financial institutions working for the development of small business (Zakon Ukrainy «Pro Natsionalnu prohramu spryiannia rozvytku maloho pidpryiemnytstva v Ukraini $\gg$ ).

This should also be facilitated by the Strategy for the Development of small and medium-sized enterprise in Ukraine, which provides for the following steps in this direction:

- expansion of lending to small and medium-sized businesses by commercial banks;

- creation of conditions for the security of deposits;

- use of loan guarantee schemes;

- activation of the use of bills;

- activation oflending to non-bankfinancial institutions;

reduction of informational asymmetry by conducting

a register of credit histories;

- reduction of the financing gap for small and medium enterprises by providing leasing services;

- reduction of financing deficit of small and medium enterprises by providing factoring services;

- use of opportunities for venture capital, attracting funds from informal investors (business angels), voluntary pooling of resources for project financing (crowdfunding);

- expansion of sources of financing of subjects of innovative small and medium enterprises;

- export financing, insurance, guarantees;

- introduction of international standards of financial reporting for small and medium enterprises (Rozporiadzhennia Kabinetu Ministriv Ukrainy «Pro skhvalennia Stratehii rozvytku maloho i serednoho pidpryiemnytstva v Ukraini na period do 2020 roku»).
For the successful introduction of optimal directions of financial and credit support of small and medium enterprises in Ukraine, a special attention is paid to the study of the features of the financial and credit mechanism in foreign countries, which determines the relevance of our research.

Problems of financing small and medium enterprises in the conditions of market transformation of the economy, determining its role in the economic development of the country were the subject of research by such scholars as A. Basiluk, M. Butko, Z. Varnalii, L. Voronin, V. Heyets, Z. Gerasimchuk, M. Kozoriz, V. Kredisov, A. Maslak, A. Melnyk, I. Myssuk, G. Reverchuk, A. Filippchenko, A. Chukhno, T. Chernyak, and others.

The purpose of the paper is to study the features of the financial and credit mechanism for supporting small and medium enterprises in foreign countries in order to identify key areas for the development of financial and credit support for small and medium businesses in Ukraine.

\section{Presentation of the main material}

Unlike Ukraine, international financial institutions are of great importance in lending to small and mediumsized businesses in Europe and in the world. So, the EU has a special program that provides for the distribution of financial assistance for small business lending through the European Bank for Reconstruction and Development, other European financial institutions.

In Europe, the European Charter for Small Enterprises adopted in 2000 is in force. The countries that joined this document consider small and mediumsized businesses as a key element of innovation and job creation. Countries are also committed to focusing on the following areas:

- education and training; creation of concessional terms for a quick start of business;

- ensuring access of small and medium-sized businesses to up-to-date information and technologies; - creation of an adequate legal and tax base that promotes the development of small and medium-sized businesses (Pidtrymka rozrobky ta vprovadzhennia Yevropeiskoi khartii dlia malykh pidpryiemstv $\mathrm{v}$ Ukraini).

The financing problem can be solved with the help of external sources, including through lending. However, there are also problems that hinder the development of lending to small and medium businesses in Ukraine. To such problems include:

- high risk of non-repayment ofloans by entrepreneurs;

- "shadow" activity of subjects of entrepreneurship;

- the high cost of loans;

- tight conditions for obtaining loans;

- insufficient economic and legal literacy of entrepreneurs;

- the short term of use of a loan; 
- the possibility of increasing interest in using a loan in unstable economic conditions, etc.;

- lack of start-up capital from entrepreneurs;

- lack of quality business plans;

- lack of credit history for start-up entrepreneurs (startups);

- the inconsistency of the financial statements of the entrepreneurs who worked under the simplified tax system, requirements of banks (in this case, it is possible to provide a loan as an individual, on bail);

- insolvency of some entrepreneurs;

- legal uncertainty in the microfinance market (Lomachynska, 2012).

One of the organizations that provide centralized financial support for small businesses in the United States is the Small Business Administration, which provides loans for the purchase of land, buildings, equipment, working capital, refinancing of existing debts and guarantees most of all long-term loans provided to small businesses programs in industry, wholesale and retail trade, services, construction, agriculture. In particular, it guarantees up to $90 \%$ of loans issued in excess of 155 thousand dollars and up to $85 \%$, if the loan amount is not less than 750 thousand dollars. The term of a loan is usually 5-7 years if the loan is issued for working capital and up to 25 years if the loan is granted for the purchase of equipment or building. In order to create more accessible conditions, small businesses receive a loan of up to $\$ 25,000$. Small business administration is implementing microcredit programs.

The forms of financial support for small and mediumsized businesses in the United States include the following:

- measures in the field of taxation, which include the gradual reduction of tax rates and the reduction of $\operatorname{tax}$ progressiveness with a narrow tax base and a wide range of tax exemptions to ensure the inflow of investments; - participation in the capital of investment companies and guaranteeing securities issued by them;

- venture financing.

Small business development is facilitated by the Innovative Development Program for Small Business, which involves allocating funds from the budget for research and development work to pay for contracts with small businesses. This program accounts for about $60 \%$ of the amount allocated by the state in the form of assistance to small businesses (Iusupova, 2001).

For small-business financial support, small business investment companies take the lead. Small business investment companies provide capital in the form of ordinary shares and continue unsecured loans to small firms that meet the investment criteria of these investment companies. Much attention is paid to the development of venture financing, as well as the development of franchising and leasing.

The instrument of financial and credit support of small enterprises is microcredit, which is used for solving such tasks as replenishment of commodity stocks or stocks of raw materials, purchase of commercial and industrial equipment, repair of premises, purchase of real estate and vehicles.

Today, in foreign countries, small banks are involved in the financing of small businesses, which have significant advantages over large ones, because local conditions and local business are better known. Small businesses prefer to take loans directly from them, because it is much more convenient, and the personal role and the status of the owner of a small business in the local community play an important role.

The main priorities for supporting small and medium-sized businesses in the UK are helping startup businesses, facilitating access to financial resources, improving enterprise management practices, developing the labour market, improving production processes, supporting innovative developments to create new products and services, and also the development of export opportunities for the small business sector.

The most important measures that ensure the achievement of the priority goals of small and mediumsized businesses include the following.

1. Assistance to start-up companies that provide free support at difficult stages of survival and formation in the form of joint consultations and guidelines that facilitate successful start-ups and the beginning of their activities.

2. Facilitating access to financial resources. A special place is the Innovative Financing Program, which focuses on providing financial support to small and medium enterprises that are involved in the development and commercialization of new innovative ideas that promote production growth, environmental protection, reducing carbohydrate consumption, saving energy and improving the competitiveness of the country, and also meet regional or national priorities. Assistance is provided to individual enterprises that are unable to meet the costs associated with the development of new products, services and technologies for:

- execution of research and development work, including protection of intellectual property rights, concept testing, marketing research, capital expenditures associated with the production of a prototype and a demonstration layout;

- involvement of partners, consultants, and patent attorneys who took part in research and development work;

- production of demonstration models of innovative developments with the use of new technologies;

- reduction of administrative costs when large companies implement innovative projects that bring great economic benefits and provide environmental protection.

3. Measures to improve the methods of management of small and medium-sized businesses, the search for specialists and the development of the labour market 
are provided by the state program "Professional DevelopmentofEmployees”.SinceApril2009, the system of state financial compensation for the costs of small and medium enterprises and individual entrepreneurs for training and advanced training has entered into force. This involves compensating entrepreneurs for the cost of mediation services, recruitment agencies, employers, and potential entrepreneurs who need a flow of highly skilled workers. These measures should provide the UK with a leading position in terms of skills levels in all sectors of the economy by 2020.

4. Improvement of production processes and an increase in their efficiency is one of the main tasks of the Government in order to ensure further sustainable economic development of the country. In this regard, the Government has developed a number of special programs for small and medium-sized businesses that provide grants and loans to small enterprises.

5. In order to develop and create new products and services that promote the competitiveness of small businesses and the national economy as a whole, the Government has developed a number of programs to provide financial assistance for the development of cooperation in the innovation field. Close cooperation in the implementation of research and development work between different enterprises and research institutes is the basis for the successful development of new technologies and products with their subsequent successful commercialization (Lebedeva, 2001).

The policy of supporting small business in Germany is based on the following principles:

- the state does not assume the initiative of realization of concrete economic projects, as this is the task of entrepreneurs themselves;

- the state encourages creative search, willingness to take risks and adaptability;

- protection against monopolistic pressure;

- indirect financial support for small businesses.

Financial support is provided at all stages of the development of small business, has a clear target and targeted character, which is determined by macroeconomic and social priorities, as well as combining different sources and measures of support.

Investment support of small enterprises is carried out, first of all, to meet the needs of enterprises in information and technological resources. Measures in this direction include economic and technical advice (financed from the state budget) both for start-ups and existing small enterprises, as well as measures for training and professional development of workers and managers of small enterprises.

Providing capital to enterprises and strengthening its economic power involves support of investments in the authorized capital (formation of initial capital at the creation of an enterprise), support of longterm investments in small business (in rationalization, modernization, expansion, transformation of production).
Credit support for newly created small businesses is carried out through the German Compensation Bank, which provides credit resources for investment purposes: for the creation or redemption of the enterprise (and related tasks during the first three years of the existence of a new firm), the redemption of an investment unit giving control over activity of the enterprise, formation of primary stocks, office equipment, etc. With the help of regional programs, lending to small enterprises focused on the production of goods and services of local importance is carried out.

The development of credit-co-operative support for small enterprises in Germany has been successfully developed. The financial basis of credit cooperatives is the own funds of small enterprises and savings of the population. Support for small businesses through the mechanism of credit cooperation allows mobilizing additional funds that were not involved in economic activity (Bryumer, 2001).

As we see, the foreign practice of functioning of the financial and credit mechanism of supporting small business is not based on the fact that, under preferential conditions, small enterprises provide the necessary financial and credit resources for their development and support small business at any cost, but to create a favourable economic and legal climate that allows small businesses not only to survive but also to develop successfully.

In world practice, the resources of various funds and grant funding organizations are a powerful source for the start-up and development of small and medium-sized businesses. An important condition is the fulfilment of the requirements of these institutions regarding the target direction and the use of funds received. Accordingly, small and medium-sized businesses should work on projects that are profitable funds and to share or give the results of developments.

In Italy, concessional long-term loans are practiced, for example, at 3-5\% per annum at a market interest rate of about $15 \%$. Enterprises can get an additional benefit of $20-30 \%$ of compensation for loan value when longterm loan repayment (Kuznietsova, 2012).

In the field of financial support, the example of the Czech Republic, which provides for the possibility of using for entrepreneurship several types of state subsidies, is indicative. First of all, these are direct grants and interest-free loans, as well as loans from commercial banks and tax incentives. Financial assistance in the form of tax breaks is very limited and is provided only to specialized industries, such as those using unconventional energy resources.

There are 4 small business promotion centres in Japan: central government, local authorities, big business, and independent small business associations. Small business support is provided at all stages of enterprise development: registration, formation, growth. To do this, use preferential loans and loans, various tax benefits, technical and advisory assistance, training, etc. 
The peculiarity of the Japanese experience of financial support for small enterprises is the provision of irreversible financial assistance (subsidies) to scientific and technical programs (Erohin, 2008).

As the financial support of small businesses, the system of tax privileges is widely used: tax rates on small enterprises' incomes make up about $27 \%$, and for large enterprises - at least 37.3\%. As in the United States, venture funds are operating in Japan, with venture capital being directed to high-tech companies: microprocessors, software development, biotechnology, etc.

By studying the foreign experience of supporting small business, China has formed its own system. The share of small enterprises in China's GDP is about $60 \%$. The Chinese government is actively supporting the development of small businesses in accordance with the principle of "seizing for the big, supporting the small." China's peculiarity is the provision of differentiated tax privileges depending on the category of enterprises.

In China, as in other foreign countries, there are state and commercial banks operating for financially-lending support of small enterprises with significant resources, minimizing and distributing risks through guaranteeing organizations. China also manages legal support for small businesses under the Law "On Stimulating the Development of Small and Medium Sized Enterprises in China". The main priority of the state in this area is the creation of favourable conditions for the activities of small enterprises if they meet the three criteria meet public demand, increase employment, ensure the implementation of state sectoral policies (Arustamov, 2012).

The features of the financial and credit mechanism for supporting small and medium-sized businesses in the foreign countries considered are as follows:

- the predominance of indirect methods of support;

- providing state financial aid only on a competitive, turnaround, and paid basis;

- an effectively functioning system of a state guarantee of loans granted by commercial banks to small enterprises (guarantee from 60 to $90 \%$ of the loan);

- creation of a network of special banks serving small businesses at different levels;
- increased financial incentives for innovation of small businesses;

- incentive system of taxation and special depreciation procedure;

- creation of conditions for equal access for all entrepreneurs to information and consulting services (especially on taxation, lending, and insurance).

\section{Conclusions}

The analysis allows us to highlight the main features of the mechanism of support for small and medium enterprises. However, it should be noted that direct transfer to the domestic economy of the American, German or another foreign model of financial and credit support of small business is not entirely appropriate. The study of foreign experience allows us to identify the general features of financial and lending support mechanisms that should be taken into account in domestic practice, in particular:

1. Availability of special legal acts defining the objectives of the state policy and regulating the entire complex of support issues for small and medium-sized enterprises, including the establishment of tasks and functions of management bodies and mechanisms for their implementation, as well as a combination of legislative and economic measures aimed at creating common favourable conditions for the development of entrepreneurial activity.

2. Allocation of appropriations for the implementation of programs of support of small enterprises from the budget; use of stimulating tax instruments; creation of specialized financial, credit, insurance and investment institutes; application of various forms and methods of financing; promotion of loans and investments in the sphere of small business through state guarantees, insurance.

3. Availability of a developed system of specialized institutions that ensure coordinated implementation of the entire complex of tasks in the field of entrepreneurship support, as well as the interaction of state authorities of various levels with business associations (unions, small business associations, chambers of commerce and industry, etc.) for the purpose of accounting their positions in making decisions.

\section{References:}

Synoverskyi, R. L. (2016). Kredytuvannia maloho ta serednoho biznesu: problemy ta perspektyvy [Lending to small and medium business: problems and prospects]. Ekonomika ta derzhava, 9, 72-76.

COSME. Europe's programme for small and medium-sized enterprises. Retrieved from: http://ec.europa.eu/ growth/smes/cosme/indexen.htm

Zakon Ukrainy «Pro Natsionalnu prohramu spryiannia rozvytku maloho pidpryiemnytstva v Ukraini» vid 21.12.2000 r. [Law of Ukraine "On the National Program for Promotion of Small Business Development in Ukraine" dated 21.12.2000]. Retrieved from: http://zakon.rada.gov.ua/laws/show/2157-14

Rozporiadzhennia Kabinetu Ministriv Ukrainy «Pro skhvalennia Stratehii rozvytku maloho i serednoho pidpryiemnytstva v Ukraini na period do 2020 roku» vid 24 travnia 2017 r. № 504-r. [The Order of the Cabinet of Ministers of Ukraine "On Approval of the Strategy for the Development of Small and Medium Enterprises in Ukraine until 2020" dated May 24, 2017 No. 504-p]. Retrieved from: http://zakon.rada.gov.ua/laws/show/5042017-\%D1\%80 
Pidtrymka rozrobky ta vprovadzhennia Yevropeiskoi khartii dlia malykh pidpryiemstv v Ukraini. Predstavnytstvo Yevropeiskoho Soiuzu v Ukraini [Support the development and implementation of the European Charter for Small Enterprises in Ukraine. Delegation of the European Union to Ukraine]. Retrieved from: http://ec.europa.eu/ delegations/ukraine/press_corner/all_news/news/2009/20090423_01_uk.htm

Lomachynska, I. A. (2012). Formüvannia dzherel finansovoho zabezpechennia rozvytku subiektiv maloho pidpryiemnytstva [Formation of sources of financial support for the development of small business entities]. Visnyk ONU imeni I.I. Mechnykova, 3-4, 37-43.

Iusupova, N. (2001). Podderzhka maloho predprynymatelstva v SShA [Small business support in the USA]. Myrovaia ekonomyka y mezhdunarodnuh otnoshenyiah, 5, 87-90.

Lebedeva, S. Yu. (2001). Regulirovanie i podderzhka malogo i srednego predprinimatelstva v ES [Regulation and support of small and medium enterprises in the EU]. Menedzhment $v$ Rossii i za rubezhom, № 1, 90-96.

Bryumer, K. (2001). Sistema podderzhki malogo predprinimatelstva v Germanii [Small Business Support System in Germany]. Dengi i kredit, № 7, 13-20.

Kuznietsova, L. V. (2012). Vplyv bankivskoi systemy Ukrainy na rozvytok maloho ta serednoho biznesu [Inflating banking system of Ukraine on small and medium business development]. Visnyk sotsialno-ekonomichnykh doslidzhen, 2(45), 249-254.

Erohin, V.L. (2008). Mezhdunarodnoe predprinimatelstvo: ucheb. posobie [International entrepreneurship: study guide]. Moskva: Finansyi i statistika.

Arustamov, E. A. (2012). Organizatsiya predprinimatelskoy deyatelnosti: ucheb. posobie [Organisation of entrepreneurship: study guide]. Moskva: Dashkov i K. 